\title{
Government Policies and Their Effects to Business in Kenya
}

\author{
Peter Muchiri Mwai \\ Regional Reach Business Consultants, Gaborone, Botswana \\ Email:peteroswana@gmail.com
}

How to cite this paper: Mwai, P.M. (2019) Government Policies and Their Effects to Business in Kenya. Open Access Library Journal, 6: e5263.

https://doi.org/10.4236/oalib.1105263

Received: February 19, 2019

Accepted: March 26, 2019

Published: March 29, 2019

Copyright $\odot 2019$ by author(s) and Open Access Library Inc.

This work is licensed under the Creative Commons Attribution International License (CC BY 4.0).

http://creativecommons.org/licenses/by/4.0/

\begin{abstract}
This paper analyzes various government policies in Kenya and how they influence business environment, with close comparisons with Botswana. Kenya is a major economic player in sub-Sahara Africa and often touted as a gateway to Africa. On the other hand Botswana is one of the few middle income countries in Africa and a beckon of democracy in Africa. The paper explores government policies and their effects to business environment in Kenya and the lessons that can be learned from Botswana as Kenya aspires to become a Middle income country by the year 2030 .
\end{abstract}

\section{Subject Areas}

Business and Economics Education

\section{Keywords}

Government Policies, Business Environment

\section{Introduction}

Kenya is one of the developing countries in the sub-Saharan Africa and until October 2014, the country has been ranked as low income country. "Kenya's population has doubled over the last 25 years, to about 40 million people, and according to recent UN projections, Kenya's population will grow by around 1 million per year over the next 40 years and will reach about 85 million by 2050"-Wolfgang Fengler (2010) [1]. Despite that according to projections the population growth has slowed down to about $2.5 \%$ compared to a high of $3.8 \%$ reported in 1979 this has been attributed to reduced fertility rates due to increased literacy levels and more government interventions resulting to increased use of family planning methods especially modern contraceptives (NCPD 2013 Page 25) [2]. Its GNI (Gross National Income) per capita was reported to be 
\$ 1160 in 2014 (Figure 1) surpassing the low-income World Bank threshold of $\$ 1036$, hence qualifying as a low middle income country [3]. World Bank released Kenya GDP in 2016 as USD 70.875 Billion (World Bank Data 2017) [4].

Botswana is another country still in sub-Saharan Africa but categorized with high economic growth rate with quite low levels of population growth and it's ranked as an upper middle income country with a population of 2 million people with an annual growth rate of $1.73 \%$ (Figure 2). The latest value for GNI per capita, Atlas method (current US\$) in Botswana was 6750.00 as 2016. Over the past

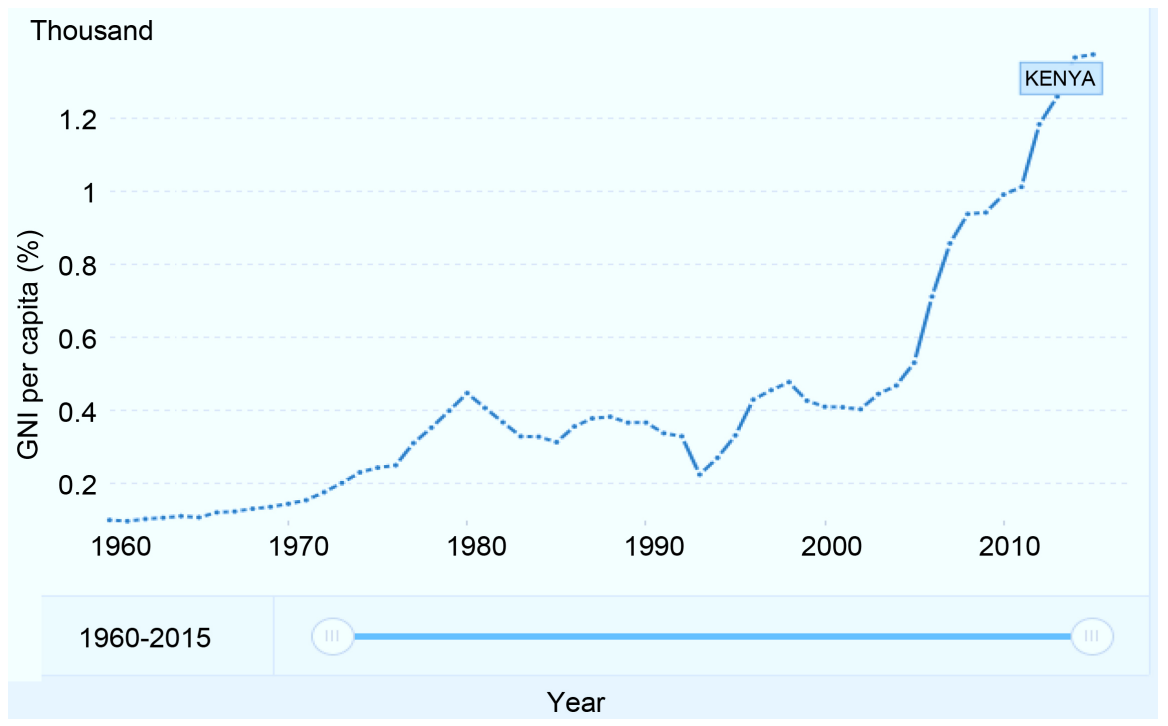

Figure 1. Kenyan gross national income per capita from 1960 to 2015. Source: http://data.worldbank.org/indicator/NY.GDP.PCAP.CD?locations=KE.

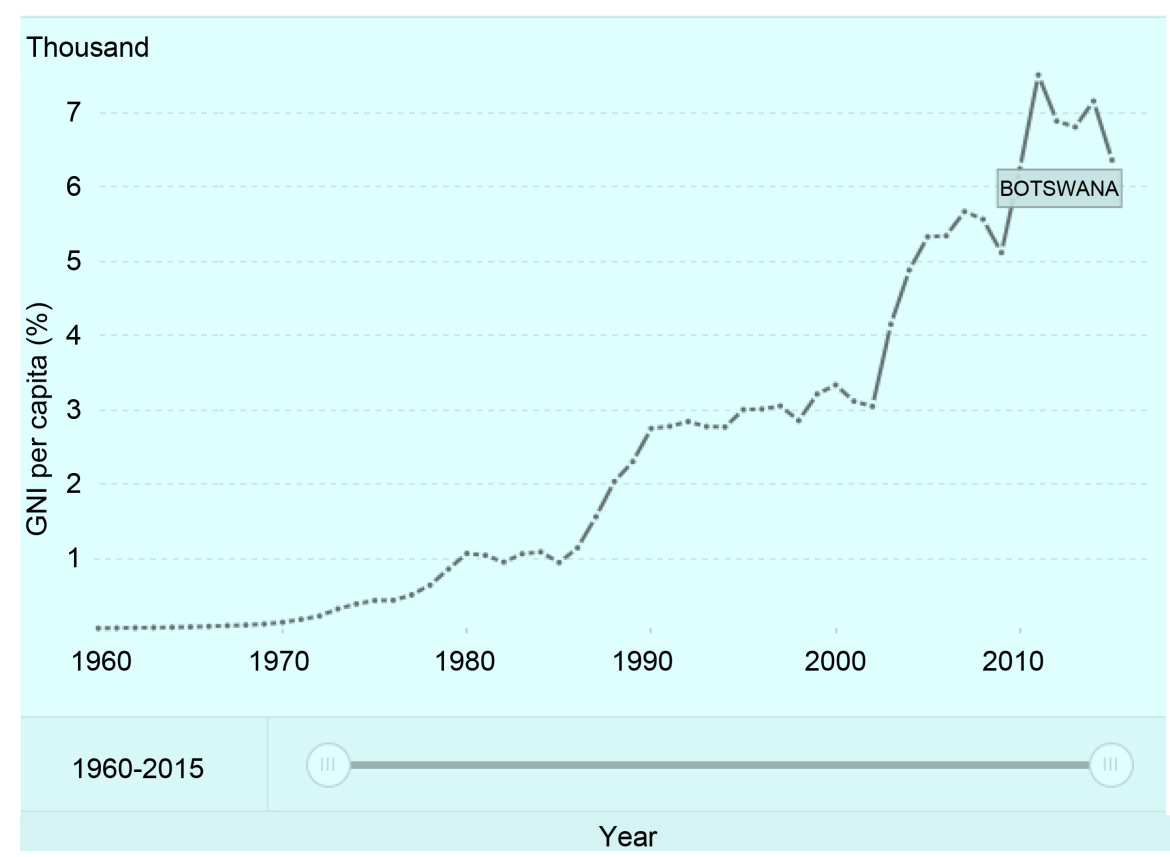

Figure 2. Botswana gross national income per capita 1960 to 2015. Source: http://data.worldbank.org/indicator/NY.GDP.PCAP.CD?locations=Bw. 
54 years, the value for this indicator has fluctuated between 7580.00 in 2013 and 70.00 in 1962 [5].

GNI per capita in Botswana in 1970 was 100.8 US dollars, and ranked 166th in the world and by 2013 the GNI per capita had grown to $\$ 7370$ registering quite a significant growth. Its GDP now stands at UDS 15.7 Billion-World Bank data files (2017). This high performance has been credited to good economic and political atmosphere coupled with good fiscal and monetary policies over the last 50 years.

Given the above background it can be noted that both countries GDP has been rising for the last 50 years, Botswana from one of the poorest country in the world to its current status as a middle income country. Its low population coupled with low population growth rates has significantly boosted its per capita income. While Kenya on the other hand has experienced tremendous economic growth rate between 1970 and 1980 as depicted by rising GNI per capita, but in 1980 s and early 1990s the country was in stagnation and sometimes negative growth was reported (See Figure 1). The population was rising quickly than the Gross National Income, putting a lot of strain in the available resources and consequently increasing the rate of unemployment. In 2003 the government implemented the Economic Recovery Strategy for Wealth and employment creation (ERS) which has seen the country's economy back to rapid growth, from lows of $0.6 \%$ in 2002 to $6.1 \%$ in 2006, as noted in Kenya Vision 2030 page 1 [6]. Currently World Bank data shows that Kenya GDP growth ranges between 5\% to $6 \%$ and it's among the few countries in the world with a considerable GDP growth. "Kenya's economy is projected to grow at 5.9\% in 2016, recording an improvement over the 5.6\% estimated for 2015, says a new World Bank Group economic report. The Gross Domestic Product (GDP) is expected to improve further to 6\% in 2017" (The World Bank Group 2016) [7]. It is under this background that this paper aims at exploring the business environment in Kenya and Botswana using international comparative advantage, and also compare how the government economic policies have influenced business policies in these two countries, as both country strive to achieve high economic growth and development. Which lessons can Kenya run from Botswana to maintain a sustainable economic Growth? In my evaluation I shall use the national output model $(\mathrm{Y}=$ $\mathrm{C}+\mathrm{G}+\mathrm{I}+\mathrm{X})$ and see how various government policies influence the model and the resulting effects tobusiness environment.

According to vision 2030, Kenya aims at becoming a middle income country by the year 2030, it has identified 3 pillars namely Economic, Social and political. They believe these pillars will make Kenya a globally competitive and prosperous nation with a high quality of life by 2030. In implementing this pillars the government aims to improve infrastructure, education and training, health care, water and sanitation, maintain a stable macroeconomic environment with stable prices and low interest rates and also maintain a peaceful environment to do business by having political stability and observation of rule of law. In this paper 
therefore I shall try to explore how government policy towards each of mentioned areas affect the business environment in Kenya in close comparisons with Botswana.

\section{Government Policies and Business Environment}

\subsection{Government Policy towards Infrastructure}

Improvement in infrastructure, is key to stimulate economic growth, the government should put more emphasizes towards improvement of the road network, electricity distribution, efficient rail network, water resources among others. Good road and railway network ensures the goods produced by the firms will be transported with ease to the destination market, with competitive transport cost hence reducing the cost of doing business. It also opens up new markets and increases interactions between various regions, with good market knowledge the challenges of distribution will largely be overcome. Reduced transportation cost, means low production cost leading to increased output and better prices for consumers, which will translate to higher consumption by consumers and firms leading to further increase in national output. The country's Production Possibility Curve shifts outward depicting increase production at all levels as the long run supply curve shifts to left as a result of increased output (See Figure 8). The consumption also boosts the aggregate demand due to increased real incomes, which in return motivates businesses to increase their output to cater for the resulting demand. The net effect of improved infrastructures is to increase output and aggregated demand for goods and services and consequently increase in the national output $(\mathrm{Y})$. A continuous improvement in infrastructure has a positive relation to the economic growth of a country. This is one area that Botswana has done well by utilizing its vast wealth in minerals exports to develop its infrastructures opening up the areas once considered inaccessible. Ian Micheler (2017), notes that by 1970 Botswana had only $12 \mathrm{~km}$ of paved roads and it was one of the poorest country in the world, after discovering diamonds, they have been able to transform the economy to register one of the highest growth rates in the world [8]. Economies Africaines (2017) says, between 1966 and 2008, the number of paved roads increased from $12 \mathrm{~km}$ to $7892 \mathrm{~km} \mathrm{[9].}$ It is also notable from Figure 2 above that its per capita income has grown from below $\$ 100.00$ in 1960 s to stand at $\$ 7523.22$ in 2017 . Though we can't attribute everything to infrastructure improvement, but it has surely contributed to this growth.

Kenya has a road network of about $177,800 \mathrm{~km}$ out of which only $63,575 \mathrm{~km}$ is classified. The classified road network has increased from $41,800 \mathrm{~km}$ at independence to $63,575 \mathrm{~km}$ today, a development rate of less than $600 \mathrm{~km}$ per annum. During the same period, the paved road length grew from $1811 \mathrm{~km}$ to 9273 km (Kenya National highway Authority 2014) [10]. Given Kenya has a high population compared to Botswana an infrastructure growth will even do more to boost business environment, increase trade and also open up rural areas for 
business. Being an agricultural nation, Kenya stands to benefit a lot from good road network which guarantees the farm produce and other consumer goods are distributed Just in Time, opening up markets hence avoiding wastage and highly improving on supply chain management. Simon Ndonga (2016) notes that the current administration has pledged to build over $10,000 \mathrm{Km}$ of tarmac road, between 2013 and 2017, and according to cabinet secretary James Macharia the pledge is still on course [11]. Although it's yet to be seen, if implemented it will be a big plus to the economy and quite an attraction to investors resulting to job creation and employment.

\subsection{Government Education Policy and Training}

Government policies related to education, will highly influence the business environment in each country, Kenya is not an exemption. Many investors will want to work in an environment where the labour force is well educated and trained. In its vision 2030, Kenya has identified this area as key to transforming its economy towards middle income country. Kenya literacy levels are still low although there is a lot of improvement in provision of universal primary education. Government policies aimed at improving education and training will have positive effects on labor productivity and skills development. Increased labour productivity means increased production in an economy further stimulating economic growth. Kenya aims at achieving an $80 \%$ adult literacy rate, increasing the net enrolment rate to $95 \%$ and increase the transition rates to technical institutions and universities from $3 \%$ to $8 \%$. It also aims at expanding access to university education from $4.6 \%$ to $20 \%$, with an emphasis in science and technology courses-(Kenya Vision 2030). In 2014 Botswana literacy level was estimated at $86.5 \%$ of population aged $10-70$ years, in overall the literacy rate was highest among the population aged (15 - 19) years at $97.8 \%$, notes statistics Botswana (2014) [12]. Kenya on the other hand has made very slow progress in literacy levels, and though Kenya adult literacy rate fluctuated substantially in recent years, it tended to decrease through $2000-2015$ period ending at $78 \%$ in 2015 [13]. A survey by the Kenya National Literacy Survey conducted in 2006 revealed that there were over 7.8 million (38.5 per cent) adults and youth who lack the minimum literacy levels while Kenyans aged between 15 and 19 years had 69.1 per cent literacy rate-Emmanuel Wanjala (2017) [14]. Low literacy levels are not good for business due to lack of necessary skills required in production and it seriously affects the productivity of labour. Investors and entrepreneurs would like to work in an environment that has high literacy levels with high labour productivity. Any government efforts towards improving education and training will most likely translate to more productivity in the long run and better work environment for business. When marginal productivity of labor goes high, this in return increases the National output hence reducing unit cost of production. Botswana has maintained high growth rate over the years, and high literacy level has created an enabling environment for doing business and wealth 
creation, Kenya should follow the suit, come up with policies aimed at boosting education and training, as way of enhancing skills in the economy.

\subsection{Government Policy on Price Stability}

High rates of inflation are not good for business, holding all things constant the quantity demanded reduces when the price goes up and vice versa. Very low prices are not also good for producers, especially if they fall below average costs of production. During the 50 years of independence Kenya has experienced very unstable price levels especially in 1980s and 1990s, during this period inflation had soared to unmanageable levels going as high as 46\% in 1993 (See Figure 4). During the same period the interest rates sky rocketed to a high of $36.24 \%$ in 1994 compared to a low of 9\% in 1972 (The global Economy.com) [15], the effects was that people including business community defaulted on their loan obligations, many business and industries closed shop due to high cost of doing business and diminishing aggregate demand, brought about by decline in real incomes. The economy growth rate stagnated and sometimes experience negative growth due to increased cost of doing business and reduced production (refer Figure 5). High domestic prices have negative effects on exports, and a positive effects on imports, as local goods and services become dearer compared to foreign goods. This in turn makes the local currency to depreciate against other foreign currencies as people give up their currency to acquire the foreign currency to buy imports. This has a net reduction in exports hence further contributing to reduction in National output. A business environment with unstable prices puts a lot of strain on businesses and consumers and the governments should put the right policies in place to stabilize the prices, they can do so through fiscal policies such as tax intervention or through government expenditure. Such interventions will be either expansionary or contractionary measures, which might be inform of reduced tax rates or increased government expenditure for an expansionary measure and increased taxes or reduced government expenditure for contractionary measures.

Figure 3 \& Figure 4 show Kenya inflation levels and GDP growth rates (Figure 5) since independence. Low inflation in 1960s to 1980 is categorized with moderate sustained growth in GDP, from USD 0.791 Billion to USD7.621 Billion (Figure 5). Inflation increased from 13.9\% in 1980 to $46 \%$ in 1993 as depicted in Figure 3 \& Figure 4, at the same period GDP contracted from USD 7.621 to USD 5.752 Billion experiencing a negative growth (See Figure 5). Negative growth in Kenya meant reduced output, not only the economy ability to create jobs was reduced, but many jobs were also lost, and the purchasing power of people was highly affected, reducing aggregate demand and sinking the country into a depression. Market forces should be allowed to allocate price levels but government should put the right fiscal and monetary policies to stabilize the market prices, when market forces fail. Government launched economic recovery programmes in 2003 and they seem to have yielded positive results, apart 


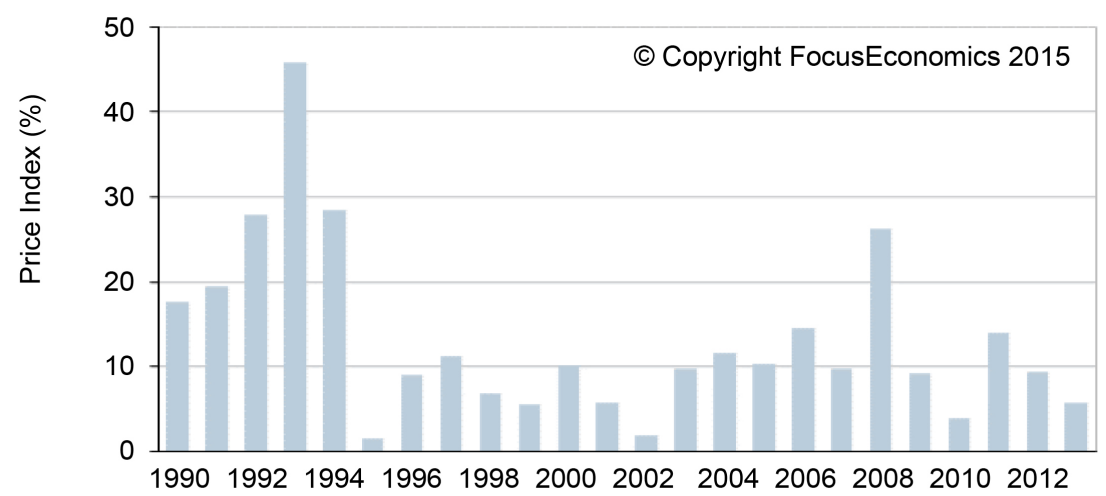

Note: Inflation, annual average variation of consumer price index (CPI) in \%. Source: Kenya National Bureau of Statistics

Figure 3. Kenya inflation levels from 1990 to 2013. Source: https://www.focus-economics.com/country-indicator/kenya/inflation.

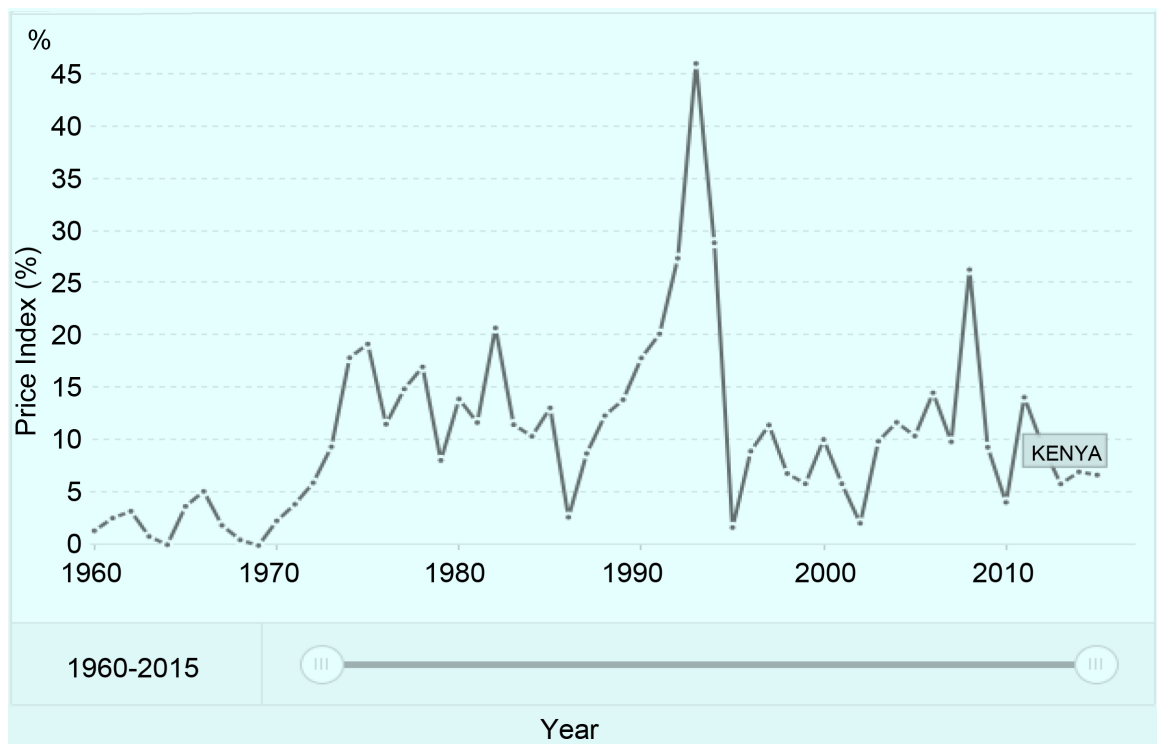

Figure 4. A line graph showing kenya inflation rates 1960-2015. Source: http://data.worldbank.org/indicator/FP.CPI.TOTL.ZG?locations=KE.

from 2008 , where inflation went as high as $26 \%$ due to reduced output as a result of 2007 post-election violence, the country has managed to maintain inflation rates below 15\% since 1994 and many times below one digit figure (See Figure 4). This has also lead to increased growth in GDP from USD 5.752 Billion in 1993 to USD 63.398 Billion in 2015, with the World Bank projecting Kenyan Economy to expand by 6\% in 2017 (See Figures 3-5).

Comparing inflation rates in Kenya with those of Botswana indicates that, while Kenya was facing hostile economic conditions in 1980s and 90s, Botswana was a success story, it managed to keep its inflation levels below 12\% apart from 1980 to 1981 and between 1989 to 1993 and later in 2008 as shown in Figure 6 . 


\section{Kenya}

GDP (current US\$)

\section{Details}

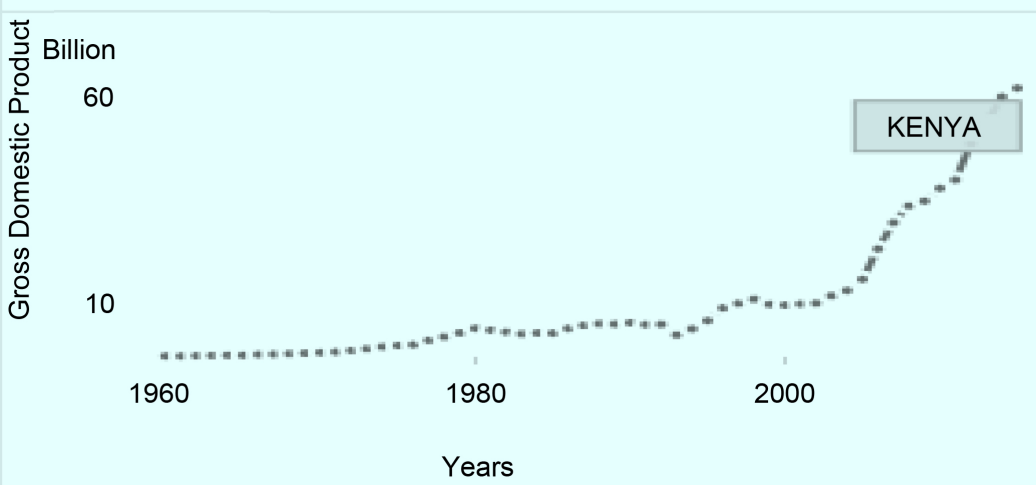

Figure 5. The figure shows Kenya Gross Domestic Product (GDP) 1960 to 2015. Source: http://data.worldbank.org/country/kenya.

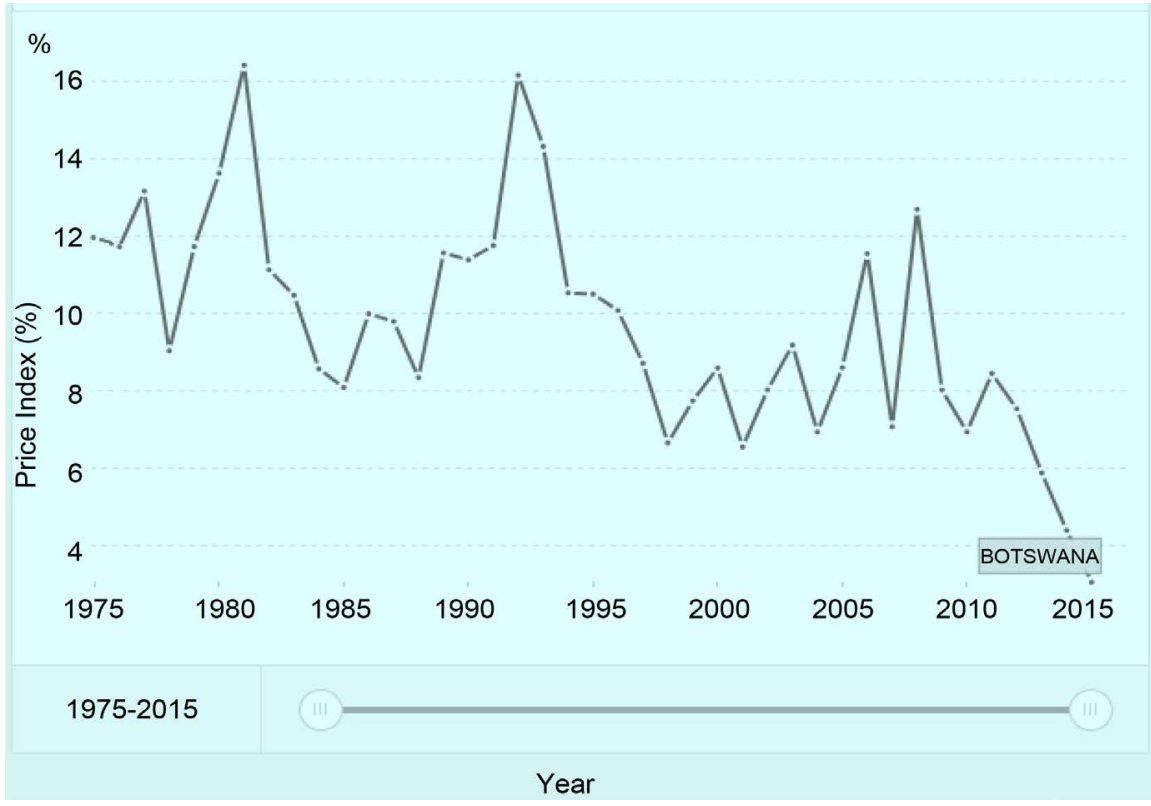

Figure 6. Botswana inflation rates 1975 to 2015. Source: http://data.worldbank.org/indicator/FP.CPI.TOTL.ZG?locations=BW.

It's good to note that during the mentioned periods there was world economic crisis, hence affecting her exports. Botswana is a net exporter's country and the economy relies more on diamonds exports and beef, hence she is highly affected by international crisis. Government is a major economy driver unlike in Kenya where private sector is quite vibrant. Reduced world prices for diamonds means reduced revenues for government, which might force the government to reduce on its national spending. Many businesses in Botswana rely on government spending making it the biggest customer to private businesses, shrinking gov- 
ernment spending means reduction in overall quantity demanded in the economy hence businesses will be forced to cut on their supplies to reduce production cost and wastage, this will shift the long run supply curve to the left signifying reduction in quantity supplied, hence increasing prices from P1 to P2 and reducing the output from Q1 to Q2 as shown in Figure 7. Since financial crisis in 2008, Botswana economy is still struggling to recover due to reduced world demand for diamonds coupled by reduced prices of the same. The economy Gross Domestic Product have been staggering around USD 15 billion since 2010 and according to Brian Benza (2016) [16] the government has embarked in Economic Stimulus programmes worth Botswana Pula 3.6 Billion (USD 0.36 Billion) to stimulate the economy and boost aggregate demand and output levels [17]. The inflation rates has been below 5\% in 2014 and 2015, and a shift from over reliance on diamonds may cushions the country from shocks brought about by world crisis. See Figure 7 on inflation rates below. All said and done, Botswana has done well in maintaining more stable prices, since independence reading to sustained GDP growth (Figure 7), while Kenya on the other hand have suffered hostile price instability, slowing down its economy especially in 1980s and 1990s. Figure 3 \& Figure 4 shows in recent times Kenya has more stable prices and at the same time the economy is expanding a bit more quickly compared with yester years as seen in Figure 5, its GNI is also on the rise as seen in Figure 1. Stable prices attract many investors, increases consumers' confidence and eventually leading to more output and consumption.

\subsection{Government Policy towards Cost and Availability of Power}

The cost of power has a direct relationship with, the cost of production and output. A business environment with very high cost of power will be categorized by low investments and high producer prices leading to high consumer prices

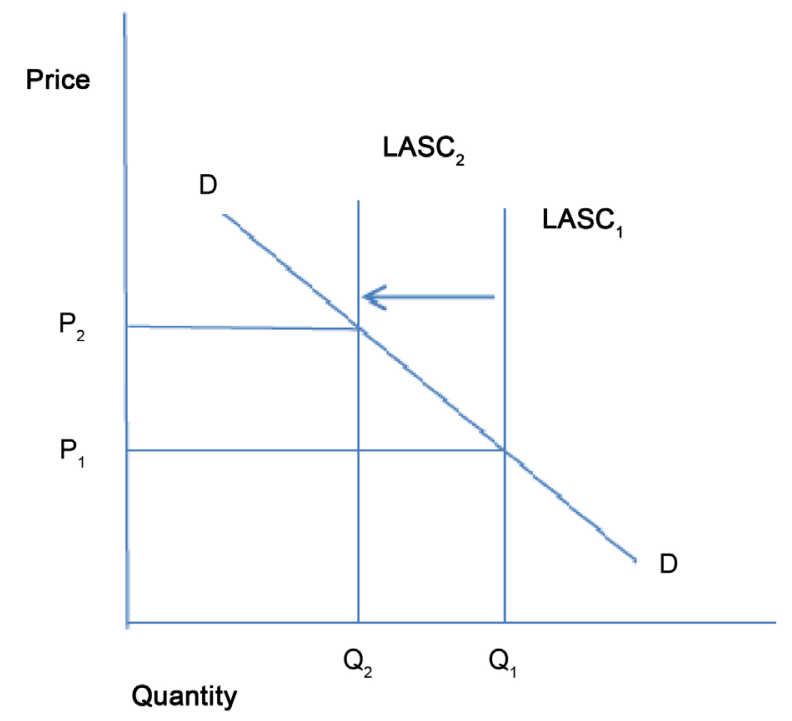

Figure 7. Reduction in quantity supplied in the economy (Long run). 
and reduced output. The country might not produce at its optimal level, hence producing inside its production possibility curve. Provision and distribution of power in Kenya is a reserve for the government. Due to the challenges associated with monopolies and market inefficiencies, cost of electricity has been high in Kenya. The distribution and generation of power has been a problem until recently, where the government has put a concerted effort to distribute power and to make it more affordable. Oxford Business Group notes, "In a bid to boost electrification nationwide, Kenya recently moved to cut electricity connection fees by over $50 \%$, while low-income customers will be able to pay the connection fee off in installments added to their monthly bill with wider efforts to boost electrification rates to $70 \%$ by 2017 " [17]. Availability of power has boosted Kenya as investment destination, but many industrialists are still calling on government to put more efforts to ensure the power is more affordable. The economy has over-relied in hydro power and fossil oils over the years; the former is unreliable due to its dependency in availability of rain while the latter is very expensive. They have now resulted to geothermal and other green energy such as solar and wind, "In Kenya vision 2030, the country's energy plan outlines how the majority of the country's electricity will come from renewable sources at utility, commercial, and industrial scale", notes Carolyn Fortuna (2018) [18]. Kenya has comparative advantage in power generation compared to Botswana which until recently was importing nearly all its power needs from neighboring countries especially South Africa. Botswana has enormous coal reserves and sunshine in abundance; hence they are able to generate enough power to sustain themselves in the years to come. In a nutshell low power costs will lead to higher production due to reduced cost of doing business, which in turn will lead to better consumer prices, leading to increased demand and increased national output. The long run aggregate supply curve (LASC1) will shift to the right (LASC2) signifying increased output from Q1 to Q2 as a result of reduction in cost of production from P1 to P2 brought about by affordable cost of power which translates low costs of doing business (See Figure 8).

\subsection{Government Policies towards Political Stability}

Every business person would like to work or invest in a peaceful environment where law and order is maintained. Political stability is a major contributor to peace and rule of law. Government policies geared towards promoting peace, national cohesion and observant of rule of law are a welcome to every business person. People would like to invest where they know their life and investments are safe. Peaceful countries are usually associated with economic growth and development, and Botswana is a good example, it is poised as a model of democracy in Africa. Other countries like DRC despite their enormous wealth in natural resources are politically unstable, and their economies have lagged behind over the years, despite their vast minerals wealth. Kenya has been fairly peaceful country, but post-election violence in 1993 and 2008 was almost to 


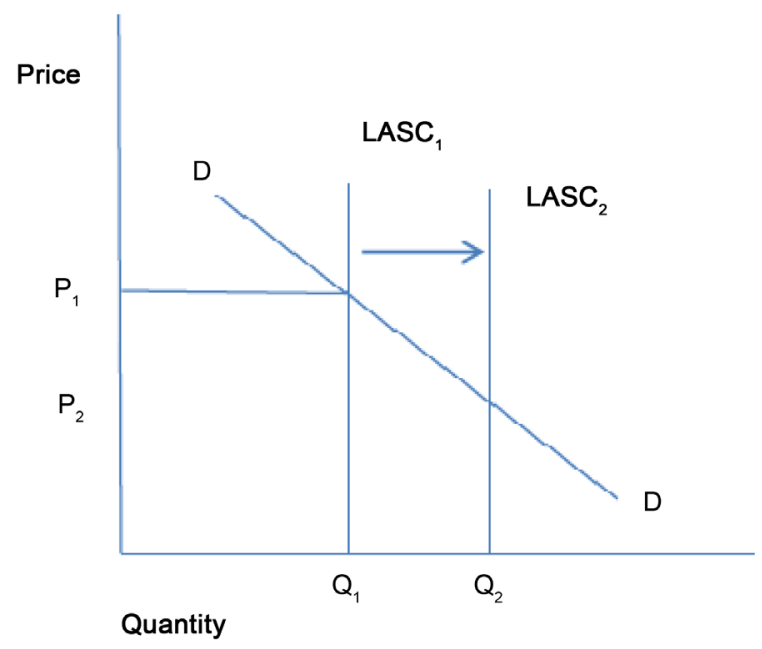

Figure 8. Effects of reduction in cost of doing business in the long run.

cripple this East African Nation. The cost of 2008 post-election violent was estimated to be, the greatest in Kenya post independent history, and Laura Guibert et al. (2012), notes that, over the period 2007-2011, per capita GDP was reduced by an average of 70 USD per year per person, which amounts to be approximately 5 percent of the 2007 baseline level. With over 40 Million people those estimates run to almost USD 3 Billion per year [19].

Property and business worth billions of dollars were destroyed, reversing all the gains experienced in the last 5 years to 2007 elections. Growth dropped from 7.1 percent in 2007 to 1.6 percent (2008), before reaching 2.6 percent in 2009; post-election violence, the food and fuels crisis, the global financial crisis and the 2009 drought almost caused the Kenya's economy to stagnate notes Johannes Zutt (2010) [20]. This is an indication of how gravies political instability can be, to countries wealth and businesses. For business to grow and expand political stability is a prerequisite and policies towards attaining political stability should be highly encouraged. The peace and political stability in Botswana has enabled the country to enjoy a fair share of growth and development, Kenya can do better also, but it needs to boost investors and entrepreneur's confidence by assuring them that the cycle of violence every five years is a thing of the past.

\subsection{Macroeconomic Environment}

Business will thrive well where government tries to maintain good macroeconomic environment, with market forces being allowed to regulate themselves without much government intervention, however there is need to ensure prices and interest rates are kept in check. Banking sector in Kenya is among the best in Africa and is well regulated by central bank. The interest rates are major driver of investments; hence business persons prefer low interest rates as source of investments. As mentioned earlier attaining price stability is crucial in ensuring sustained growth. Low interest is also necessary to stimulate investment demand 
in an economy. Due to reasons already mentioned above such as unstable prices, political instability and high government borrowing, the lending institutions has maintained interest rates high in Kenya. Some say the banks sometimes they are reluctant to bring interest rates low, attracted by high profits. In view of this parliament just recently pegged the interest rates to government prime rate, with a hope of bringing interest rates to no more than $4 \%$ above the prime. This new legislation was in response to the public view that lending rates in Kenya were too high, and that banks were engaging in predatory lending behavior. The interest rate caps were therefore intended to alleviate the repayment burden on borrowers and improve financial inclusion as more individuals and firms would be able to borrow at the lower repayment rates Bilal Zia and Mehnaz Safavian (2018) [21]. Most banks have been charging more than $20 \%$ in interest making it difficult for many people to borrow especially SMEs, hence government intervention. According to Kamal Bhattacharya and Tavneet Suri (2016), majority of countries are using caps to curtail exorbitant and unconscionable interest rates on loans (frequently referred to as usury). Hence, interest rate caps could be considered as a policy intervention to drive down the cost of loans for consumers [22]. Markets are supposed to regulate themselves without much government interventions and economists are still analyzing how the events will unfold and how the banks will respond. Developed countries like USA have been able to maintain low interest rates and hence making big strides in economic growth and development. Botswana has also fared well and according to trading economics.com its benchmark interest rates were at $6 \%, 5.5 \%$ and 5\% in 2016, 2017 and 2018 respectively [23]. Kenya need to do more to ensure it maintains stable macroeconomics environment by maintaining low interest rates and moderate inflation rates. In national income theory, low interest will lead to increase in investment, higher investments means increased production at lower costs as result of low price of doing business brought about by low interests rates, this will eventually lead to increase in real income and consumption, creating jobs and employment as economy output increases.

\subsection{Universal Health Care and Sanitation}

A universal health care and sanitation should be one of the major government policies in its comprehensive and long range plans. A health nation is productive and saves the country a lot of resources in treatment of preventable diseases. Kenya is still far from achieving a universal health care though it's one of its major targets in vision 2030. A business environment with very poor health facilities is never attractive to business; productivity of labour is highly affected due sickness, sick leaves and lack of morale among the workers. Sickness depletes individual's wealth as a result of high cost of treatment hence Universal care ensures every citizen has equal chances for treatment without necessary spending all their fortunes on treatment and medication. Developed countries have made a lot of progress in health care but many developing countries are still 
struggling, although Countries like Mauritius and Botswana are also doing well in provision of universal health care. Kenya government through NHIF (National Hospital Insurance Fund) is trying to implement this policy, and according to the World Bank, the chances of success are good, the goal is to provide everyone with affordable access to health care, ensure availability of essential medicines, and reduce out-of-pocket payments [24]. Success in universal health care will be good for the country, for many reasons; one a lot of resources spent in treatment and medicine can be consumed in other goods and services or be saved for future investments, leading to increase growth and prosperity. Business will benefit more by increased supply of healthy and productive work force, this in the long run will also lead to increased productivity of labour, hence reducing the unit costs of production. With reduced average costs due to increased productivity, businesses are able to produce more goods and services, hence increasing National Output.

\section{Conclusion}

In conclusion government policies have a great influence on business environment and the need for the governments to create an enabling environment to conduct business cannot be over emphasized. Some policies can be good while others are bad for business; hence governments and regulators need to weigh their actions, and evaluate how these actions may affect the business environment. It's upon all government, Kenya included to implement the right policies to ensure that they create a good and conducive environment for conducting businesses, which is aimed at increasing entrepreneurs and investors. This in return will enable the business sector to thrive and expand leading to increased consumption and higher National output.

\section{Conflicts of Interest}

The author declares no conflicts of interest regarding the publication of this paper.

\section{References}

[1] Fengler, W. (2010) Demographic Transition and Growth in Kenya. http://www.worldbank.org/en/news/opinion/2010/04/28/demographic-transition-gr owth-kenya

[2] National Council for Population and Development (2013) Kenya Population Situation Analysis.

https://www.unfpa.org/sites/default/files/admin-resource/FINALPSAREPORT_0.pdf

[3] Copley, A. (2014) Kenya Rebases GDP and Becomes Ninth-Largest African Economy. The Brookings Institution.

https://www.brookings.edu/blog/africa-in-focus/2014/10/03/africa-in-the-news-ken ya-becomes-a-middle-income-country-mo-ibrahim-index-released-south-sudan-pe ace-talks-yield-promise/

[4] The World Bank Group (2019) Kenya. The World Bank Group. 
https://data.worldbank.org/country/kenya

[5] IndexMundi (2017) Botswana-GNI per Capita.

https://www.indexmundi.com/facts/botswana/gni-per-capita

[6] https://vision2030.go.ke/

[7] The World Bank Group (2016) Kenya's Economy Strong in a Challenging Global Environment. Says World Bank.

http://www.worldbank.org/en/news/press-release/2016/03/31/kenyas-economy-stro $\underline{\text { ng-in-a-challenging-global-environment-says-world-bank }}$

[8] Micheler, I. (2017) The Emerging Nation. Siyabona Africa (Pty)Ltd. http://www.botswana.co.za/History_of_Botswana-travel/botswana-country-guide-i nsiders-guide.html

[9] Economies Africaines (2017) The Road Network. Conception CSI. https://tradingeconomics.com/botswana/gdp-per-capita

[10] Kenya National Highways Authority (2014) Classified Road Network. http://www.kenha.co.ke/index.php?option=com_content\&view=article\&id=46\&Ite $\underline{\operatorname{mid}=54 \& \text { showall }=1}$

[11] Ndonga, S. (2016) Kenya: Government on Course to Build 10,000 km of RoadsMacharia. https://allafrica.com/stories/201605140131.html

[12] Statistics Botswana 2016-2019. http://www.statsbots.org.bw/

[13] Knoema Corporation (2015) Kenya-Adult (15+) Literacy Rate. https://knoema.com/atlas/Kenya/topics/Education/Literacy/Adult-literacy-rate/

[14] Wanjala, E. (2017) Survey on Kenya's Literacy Levels to Be Conducted. Star. www.the-star.co.ke/news/2017/11/26/survey-on-kenyas-literacy-levels-to-be-condu cted_c1675993

[15] The GlobalEconomy.com (2019) Kenya: Lending Interest Rate. https://www.theglobaleconomy.com/Kenya/Lending_interest_rate/

[16] Benza, B. (2016) Stimulus Budget at P3.6bn So Far. Dikgang Publishing Company. http://www.mmegi.bw/index.php?aid=57544\&dir=2016/february/05

[17] Oxford Business Group (2019) Affordability of Kenya's Electricity Central for Expanding Access.

https://oxfordbusinessgroup.com/analysis/price-right-affordability-central-efforts-e xpand-access-electricity

[18] Fortuna, C. (2018) Renewable Energy in Kenya: Meeting the Needs of an Expanding Population. Sustainable Enterprise Media Inc.

https://cleantechnica.com/2018/04/16/renewable-energy-in-kenya-meeting-the-nee ds-of-an-expanding-population/

[19] Guibert, L. and Perez, G. (2012) Measuring the Economic Cost of the 2007/08 Post-Election Violence in Kenya.

https://editorialexpress.com/cgi-bin/conference/download.cgi?db_name=CSAE201 3\&paper_id=75

[20] Zutt, J. (2010) Kenya Economic Update. World Bank Poverty Reduction and Economic Management Unit Africa Region.

http://siteresources.worldbank.org/KENYAEXTN/Resources/Kenya-Economic-Up date-June-2010.pdf

[21] Zia, B. and Safavian, M. (2018) To Cap or Not to Cap? What Does Kenya's Experience Tell Us about the Impact of Interest Rate Caps on the Financial Sector? The World Bank Group.

http://blogs.worldbank.org/allaboutfinance/cap-or-not-cap-what-does-kenya-s-exp 
$\underline{\text { erience-tell-us-about-impact-interest-rate-caps-financial-sector }}$

[22] Bhattacharya, K. and Suri, T. (2016) Dilemma of Capping Bank Interest Rates in Kenya. Business Daily.

https://www.businessdailyafrica.com/Opinion-and-Analysis/Dilemma-of-capping-b ank-interest-rates-in-Kenya/539548-3369400-item-0-14x3f96z/index.html

[23] Trading Economics (2019) Botswana Interest Rate.

https://tradingeconomics.com/botswana/interest-rate

[24] World Bank (2015) The Path to Universal Health Coverage in Kenya: Repositioning the Role of the National Hospital Insurance Fund. Smart Lessons.

http://documents.worldbank.org/curated/en/832461468188355009/pdf/99070-BRI-I FC-586467-SMART-LESSONS-Box393181B-PUBLIC-20150624T081248-2015-Univ ersal-Health-Coverage-Kenya-C.pdf 